Karol Kuźmicz

\title{
Wpływ filozofii kantowskiej na poglądy filozoficznoprawne Eugeniusza Jarry
}

Keywords: Kant's philosophy of law, natural law

\section{Summary}

Eugeniusz Jarra (1881-1973) was a historian of philosophy of law, working on Warsaw University till 1939, then he emigrated to France and subsequently to England. Although he wasn't a member of Kant's school of philosophy, but you can find distinct connections with Kant's philosophy. Jarra was closer to Christian philosophy and to social doctrine of the Catholic Church.

He believed that the natural law is a psychical experience and this places him among the representatives of so called gnoseological theories of natural law with changing content. For him the natural law was the internal "voice of equity" and also the ideal pattern of positive law. Eugeniusz Jarra treated natural law as a demand addressed to legislative power and as an element of state's policy of law.

Jarra also saw connections between Kant's conception of state as „unification of human beings under the power of acts" with his idea of citizens' unity. The concept of state presented by Jarra, in which citizens' duties play dominant role, can be close to authoritarian or even totalitarian concept of state. This shows that Jarra was only superficial in sharing Kant's views.

\section{Działalność naukowa Eugeniusza Jarry}

Starając się odnaleźć inspiracje kantowskie w poglądach polskich filozofów i teoretyków prawa okresu międzywojennego, nie można przejść obojętnie obok dorobku naukowego Eugeniusza Jarry. Wydaje się jednak, iż uczony ten był nie tyle filozofem prawa, co historykiem filozofii prawa. Jednakże jego poglądy fi- 
lozoficznoprawne stanowiły, zdaniem S. Czepity, pewnego rodzaju „mezalians psychologistycznej teorii prawa $w$ wersji nadanej jej przez L. Petrażyckiego $z$ ideami pozytywistycznymi i prawnonaturalnymi, ujętymi przy tym w sposób wysoce uproszczony"'. W tym kontekście stanowisko filozoficznoprawne E. Jarry zalicza się zazwyczaj do nurtów psychologicznych, jako że istotę prawa sprowadzał on do przeżycia psychicznego, jego teoria prawa natury mieści się w ramach teorii gnoseologicznych, które wywodzą swój początek z filozofii Kanta². Wątków kantowskich w poglądach filozoficznoprawnych E. Jarry jest jednak kilka, ale by je zauważyć należy wyzbyć się wszelkich uproszczeń, o których wspomina cytowany wyżej S. Czepita. W związku z tym nie można z góry zakładać, iż stanowisko E. Jarry odpowiada założeniom jednej tylko szkoły czy teorii, lecz jest syntezą dotyczącą rozmaitych doktryn, mającą przy tym najczęściej charakter opisowy. Uczony dał temu wyraz w swoich koncepcjach teoretycznoprawnych, związanych nie tylko z zagadnieniem prawa natury, ale także z pojęciem normy, w tym normy prawnej. Jak większość filozofów i teoretyków prawa dwudziestolecia międzywojennego - musiał on określić swoje stanowisko wobec filozofii prawa i ogólnej teorii prawa. Inspiracje kantowskie w poglądach E. Jarry można też znaleźć przy opisywaniu przez niego relacji zachodzących między prawem a moralnością oraz charakteryzowaniu pojęcia słuszności. Jak zauważa M. Szyszkowska, to ostatnie identyfikował on $\mathrm{z}$ treścią prawa natury ${ }^{3}$, która odpowiadając kantowskiej i neokantowskiej nauce prawa była zmienna. Z filozoficznoprawnego punktu widzenia interesujący wydaje się również fakt poszukiwania przez E. Jarrę źródeł i uzasadnienia dla idei jedności obywatelskiej w dziejach. W ich kontekście określił on także wpływ Kanta na tę ideę, z którą niekoniecznie można się dzisiaj zgadzać. Potwierdza to tylko istnienie wielu możliwych interpretacji myśli kantowskiej, często bardzo różniących się od siebie. Jedną z takich interpretacji dokonał właśnie E. Jarra.

Eugeniusz Jarra żył w latach 1881-1973. Uczęszczał do II Gimnazjum Filologicznego w Warszawie, będąc zarazem słuchaczem tajnych wykładów z literatury polskiej. Mimo iż studia prawnicze rozpoczął na Uniwersytecie Warszawskim, to jednak w 1905 r., w wyniku represji za uchwałę młodzieży akademickiej o polonizacji uczelni, został zmuszony do ich przerwania w swoim rodzinnym mieście i przeniesienia się za granicę4. Następnie kontynuował naukę najpierw na uniwersytecie w Odessie, gdzie uzyskał dyplom I stopnia, a od 1906 do 1908

1 S. Czepita, Koncepcje teoretycznoprawne w Polsce międzywojennej, „Czasopismo Prawno-Historyczne" 1980, t. XXXII, z. 2, s. 111; zob. K. Motyka, Wplyw Leona Petrażyckiego na polska teorię i socjologię prawa, Lublin 1993, s. 37-39 i 131-133.

2 Por. M. Szyszkowska, Teorie prawa natury XX wieku w Polsce, Warszawa 1982, s. 120-121.

3 Ibidem, s. 122.

${ }^{4}$ R. Polak, Jarra Eugeniusz, [w:] Powszechna encyklopedia filozofii, t. V, M. A. Krąpiec (przew. Kom. Nauk.), Lublin 2004, s. 267; por. C. Kunderewicz, Eugeniusz Jarra 1881-1973. W trzecia rocznice zgonu, Zeszyty Naukowe KUL 1976, t. XIX, z. 3 (75), s. 102-103. 
roku w Bonn na Wydziale Filozoficznym ${ }^{5}$. Studia wyższe ukończył jednak na Uniwersytecie Jana Kazimierza we Lwowie, gdzie później także się doktoryzował. Po studiach wykładał prawo na Wyższych Kursach Handlowych w Warszawie, przekształconych następnie w Wyższą Szkołę Handlową (późniejsza SGH). Doktorat uzyskał z filozofii dopiero w 1918 r., obroniony na Uniwersytecie we Lwowie, na podstawie pracy: Idea państwa u Platona i jej dzieje. Dowodził w niej, iż dzieje platońskiej idei państwa to przede wszystkim historia wpływów myśli tego filozofa na następne wieki ${ }^{6}$. Po doktoracie E. Jarra wykładał encyklopedię i filozofię prawa na Uniwersytecie Warszawskim, gdzie od 1920 r. był profesorem nadzwyczajnym, a od 1923 r. profesorem zwyczajnym. Od 1923 r., przez 6 lat, był również dziekanem Wydziału Prawa i Administracji UW, aż do roku $1929^{7}$. Dodatkowo nadal prowadził wykłady z prawa cywilnego w Szkole Głównej Handlowej. Wielokrotnie wyjeżdżał na wykłady z zakresu filozofii prawa za granicę, m.in. do Pragi, Bratysławy, Brna w 1926 r., Padwy i Rzymu w 1927 r. oraz do Lille w 1933 r., gdzie nadano mu tytuł doktora honoris causa tamtejszego uniwersytetu, i do Paryża w 1937 r. ${ }^{8}$ Odznaczono go wieloma orderami, np. we Francji - Krzyżem Oficerskim francuskiej Legii Honorowej, a w Polsce Krzyżem Komandorskim Orderu Odrodzenia Polski.

Od 1920 r. E. Jarra pełnił funkcję sędziego Sądu Apelacyjnego w Warszawie, a w 1924 r., ze względu na sprawowanie w tym czasie funkcji dziekana na UW, zrezygnował z nominacji na sędziego Sądu Najwyższego'. Po wybuchu II wojny światowej udał się na emigrację, najpierw do Francji, gdzie brał udział w pracach rządu gen. Władysława Sikorskiego oraz wykładał na Wydziale Prawa w Paryżu do 1940 r. ${ }^{10}$ Po klęsce Francji przeniósł się już na stałe do Wielkiej Brytanii, gdzie od 1944 do 1947 r. wykładał filozofię prawa na oksfordzkim uniwersytecie. Nigdy nie wrócił do Polski, choć cały czas związany był sentymentalnie z krajem. Należał do Polskiego Towarzystwa Naukowego na Obczyźnie i współtworzył emigracyjne czasopismo kulturalno-naukowe „Horyzonty”. Propagował wówczas polską myśl polityczno-prawną, zwłaszcza Rzeczypospolitej przedrozbiorowej oraz katolicką naukę społeczną, która stała się mu najbliższa. Zmarł w Oksfordzie 28 sierpnia 1973 r., w wieku 92 lat.

${ }^{5}$ Por. Czy wiesz kto to jest?, z. 1, red. S. Łoza, Warszawa 1938, s. 294.

${ }^{6}$ E. Jarra, Idea państwa u Platona i jej dzieje, Warszawa 1918, s. 3.

Zob. idem, Wspomnienia o Uniwersytecie Warszawskim 1915-1939, Londyn 1972; Wydział Prawa $w$ relacjach $i$ wspomnieniach pracowników i studentów (1918-1950), „Studia Iuridica”, t. XVII, red. G. Bałtruszajtys, Warszawa 1990.

8 Por. R. Polak, Jarra Eugeniusz, op. cit., s. 267; G. Bałtruszajtys, Wydział Prawa na Odrodzonym Uniwersytecie Warszawskim, [w:] Z dziejów Wydziału Prawa Uniwersytetu Warszawskiego. 75 lat działalności Wydziału Prawa Odrodzonego Uniwersytetu Warszawskiego. Materiały z sesji - luty 1994 r., „Studia Iuridica", t. XXIX, red. G. Bałtruszajtys, Warszawa 1995, s. 18.

9 Por. ibidem, s. 267-268.

10 Ibidem, s. 268; zob. J. Sawicki, Tajny Wydział Prawa Uniwersytetu Warszawskiego w latach 1939-1944, [w:] Studia z dziejów Wydziału Prawa Uniwersytetu Warszawskiego, red. B. Leśnodorski, Warszawa 1963, s. 193 i 203. 
W swojej długoletniej pracy naukowej opublikował szereg rozpraw i artykułów, głównie o tematyce filozoficznoprawnej, ale nie tylko. Jeszcze przed obroną doktoratu w 1916 r. wydał w Bernie książkę o Politycznej i administracyjnej organizacji Królestwa Kongresowego, a w 1918 r. swój pierwszy artykuł w „Gazecie Sądowej Warszawskiej” pt. Codex Iuris Canonici. W 1920 r. ukazało się pierwsze wydanie jego Ogólnej nauki o prawie, natomiast trzy lata później podręcznik z Historii filozofii prawa. Na uwagę zasługuje też opublikowany przez niego w 1937 r., na łamach „Themis Polska”, artykuł pt. Jedność obywatelska w dziejach filozofii prawa. W tym czasie E. Jarra rozpoczął pionierskie badania nad mało jeszcze znanymi doktrynami polityczno-prawnymi dawnej Polski, do których zachęcał też swoich uczniów ${ }^{11}$. W wyniku tego szczytnego zamierzenia opublikował szereg opracowań poświęconych wybranym myślicielom tego okresu, nie tylko $\mathrm{w}$ języku polskim, ale także włoskim, angielskim i francuskim ${ }^{12}$. W Londynie ukazała się jego Teoria prawa, część pierwsza w 1942 r., a w 1972 r. Wspomnienia o Uniwersytecie Warszawskim. Pozostając do końca życia na obczyźnie, E. Jarra publikował najczęściej swoje artykuły w polonijnych „Horyzontach”"13. Ważnym elementem naukowego dorobku E. Jarry było również opisywanie prawnych relacji między państwem a Kościołem ${ }^{14}$, a po II wojnie światowej zdecydowane propagowanie myśli społecznej Kościoła katolickiego ${ }^{15}$. W tym kontekście należy więc się skupić przede wszystkim na poglądach E. Jarry z okresu międzywojennego, wyjątkowo przywołując jednak jego poglądy późniejsze. Jest

${ }^{11}$ Por. K. Opałek, W. Wolter, Nauka filozofii prawa i prawa karnego w Polsce, Kraków 1948, s. 17; zob. W. Wąsik, Prace profesora Eugeniusza Jarry i jego uczniów, „Przegląd Filozoficzny” 1936, z. 39, s. 302-311. Podejmując podobną problematykę pod kierunkiem prof. E. Jarry, w 1925 roku napisał doktorat o Pogladach filozoficzno-prawnych Szymona Starowolskiego - jeden z jego najzdolniejszych uczniów - Henryk Piętka.

${ }^{12}$ Zob. np. E. Jarra, L'idea della libertà nella litteratura politica polacca del secolo decimosesto, „Rivista Internazionale di Filosofia del Diritto", Roma 1928; L'idea dell' Assoluto nella Filosofia giuridica polacca, [w:] Studi Filosofico-giuridici dedicati a Georgio del Vecchio, vol. I, Modena 1930; Wawrzyniec Goślicki jako filozof prawa, „Themis Polska” 1931; Aron Aleksander Olizarowski jako filozof prawa, [w:] Ksiega pamiątkowa celem uczczenia 350-letniej rocznicy założenia Uniwersytetu Stefana Batorego $w$ Wilnie, Warszawa 1931; Le Bodinisme en Pologne au XVII-ème siècle, „Archives de Philosophie du Droit et Socjologie Juridique”, Paris 1933; Monumentum Ostroroga w świetle filozofii prawa, „Themis Polska" 1933; Andrew Wolan. Sixteen Century Polish Calvinist Writter and Philosopher of Law, [w:] Studies in Polish and Comparative Law, London 1945, s. 124-155.

${ }_{13}^{13}$ Zob. idem, Styczności kulturowe Rzplitej Polskiej z Anglia, „Horyzonty” 1970, rok XV, nr 166-167, s. 3-17 oraz 23-40; Powołanie prawników wśród nieprawników, „Horyzonty” 1970, rok XV, nr 173-174, s. 41-64.

${ }^{14}$ Idem, Elements religiueux dans la législation polonaise. Rapport au Congrès Internationale de Droit comparé à la Haye, en août 1932, „Themis Polska” 1932; Relations ethnologique et historique entre la Religion et le Droit. Rapport générale au Congrès Internationale de Droit comparé à la Haye, en août 1932, Sirey 1934.

${ }^{15}$ Idem, Kardynał Jan Henryk Newman. 1801-1845-1890, Londyn 1945; Człowiek a władza, Londyn 1947; Socjologia katolicka, Londyn 1953; Kardynał Wyszyński, prymas - socjolog, Londyn 1956; $\mathrm{Na-}$ uka społeczna kardynała Augusta Hlonda Prymasa Polski, Londyn 1958; Historia polskiej filozofii politycznej 966-1795, Londyn 1968; Jednolitość filozofii politycznej Polski przedrozbiorowej, Londyn 1972. 
to o tyle ważne, iż zasadniczo swoje stanowisko filozoficznoprawne ukształtował on w okresie międzywojennym.

\section{Filozofia prawa}

Określając przedmiot i zadania ogólnej teorii prawa, E. Jarra stwierdził, że powinna ona analizować podstawowe i wspólne dla wszystkich nauk prawnych pojęcia $^{16}$. Teoria prawa dąży bowiem do naczelnych pojęć w nauce prawa i najwyższych w niej uogólnień, takich jak chociażby: pojęcie prawa, jego istota oraz stosunek do innych norm społecznych, źródła prawa, stosunek prawny i jego elementy, akt prawny, wreszcie podział prawa na publiczne i prywatne, przy czym „[...] im bardziej komplikuje się wiedza prawnicza, tym silniejsza jest potrzeba nauki jednoczącej dążenia odśrodkowe, traktujące o pojęciach, którymi operują wszystkie specjalne nauki prawne [...]"17. Jak twierdzi S. Czepita, teoria prawa nie była wbrew pozorom nauką drugiego stopnia w stosunku do innych, szczegółowych nauk prawnych, gdyż w intencji E. Jarry analiza podstawowych pojęć prawnych była jedynie środkiem do formułowania $\mathrm{w}$ ramach teorii prawa - twierdzeń o rzeczywistości - twierdzeń o szczególnego rodzaju zjawiskach psychicznych ${ }^{18}$. Tak rozumiana teoria prawa różniła się - jego zdaniem - od innych nauk prawnych o charakterze ogólnym, takich jak np. encyklopedia prawa, filozofia prawa, czy wstęp do nauk prawnych.

Wśród pomocniczych nauk prawnych - obok historii, psychologii, czy językoznawstwa - znalazła się także filozofia jako nauka pierwszych i najbardziej ogólnych zasad. Niegdyś obejmowała ona całą wiedzę ludzką; gdy nastąpił podział na nauki szczegółowe - filozofia stała się łącznikiem między poszczególnymi dziedzinami wiedzy. W ten sposób filozofia jednoczy wyniki innych nauk, a jej samodzielna rola sprowadza się do poddawania ocenie i kontroli materiału otrzymanego od tamtych, a jak chcieliby niektórzy, „na wskazywaniu tego, co być powinno, badaniu celu i sensu wszechrzeczy"19. Wszystkie nauki z niej brały początek, w tym nauka prawa, którego naukowe badanie jest niemożliwe bez znajomości filozofii starożytnej, średniowiecznej i nowożytnej ${ }^{20}$. Zastosowanie filozofii do prawa dało swój początek takim naukom jak filozofia prawa, mająca za zadanie: „całkować nauki prawne za pomocą wyprowadzania jedności ich najogólniejszych zasad; wyjaśniać te ostatnie, względnie krytykować z punktu widzenia pewnych postulatów prawa idealnego" ${ }^{21}$; oraz historia filozofii prawa,

\footnotetext{
${ }^{16}$ Por. idem, Ogólna teoria prawa, Warszawa 1922, s. 32 i n.

${ }^{17}$ Idem, Teoria prawa, cz. I, Londyn 1942, s. 3.

${ }^{18}$ Por. S. Czepita, Koncepcje teoretycznoprawne w Polsce..., s. 119.

${ }^{19}$ E. Jarra, Ogólna teoria prawa..., s. 9.

${ }^{20}$ Idem, Teoria prawa, s. 4.

${ }^{21}$ Idem, Ogólna teoria prawa..., s. 9.
} 
obejmująca z kolei dzieje doktryn o prawie, państwie i społeczeństwie ${ }^{22}$. Jeżeli więc rozumowania prawne, powołujące do życia poszczególne teorie prawne, można nazwać filozofowaniem o prawie, to na tej podstawie historia filozofii prawa obejmuje rozwój poglądów ludzkich na prawo, ich historyczne następstwa i zależności²3. Historia filozofii prawa, jak wskazuje na to jej nazwa, leży na pograniczu prawa i filozofii, przy czym filozofia występuje tu w charakterze nauki pomocniczej dla prawa, a więc $\mathrm{z}$ natury rzeczy została uwzględniona tylko w tej mierze, w jakiej było to usprawiedliwione ze stanowiska jej naczelnego zadania, a mianowicie - wyjaśnienia idei prawno-państwowych ${ }^{24}$. W tym kontekście historia filozofii prawa i państwa daje obraz zabiegów podejmowanych od wieków przez rozum ludzki w celu rozwiązania najbliższych jednostce oraz ogółowi i najbardziej przy tym palących zagadnień bytu zbiorowego ${ }^{25}$. Dzieje te nie mają jednak znaczenia wyłącznie teoretycznej rejestracji przeróżnych poglądów na prawo, gdyż „każda wchodząca tu w rachubę teoria, niezależnie od swej wartości absolutnej, trafności czy błędności, użyteczności czy szkodliwości, wywierała wpływ mniejszy lub większy na rzeczywistość historyczną, stając się przeto czynnikiem współokreślającym ją, a więc i tłumaczącym [...]. Stąd dzieje filozofii prawa nie tylko służą swym celom badawczym, lecz poza tym są wykładnikiem rozwoju tych związków społecznych, w których odnośne doktryny prawne powstały lub znalazły gościnę"26.

W tym miejscu należy zwrócić uwagę na krytyczną recenzję E. Bautro, który zarzucał E. Jarze „nieopanowanie do głębi prądów i problemów ogólnych nauk prawnych" ${ }^{27}$. Według niego w podręczniku E. Jarry Historia filozofii prawa „uderza niezdecydowanie autora $\mathrm{w}$ określeniu zadań i przedmiotu filozofii w ogóle, a w szczególności filozofii prawa tudzież ich dziejów [...] autor nie ujmuje należycie ani istoty filozofii, ani jej stosunku do poszczególnych nauk"28. Wydaje się, że niektóre $\mathrm{z}$ uwag E. Bautro są jednak nieco przesadzone, a podręcznik ten, który był jednym $\mathrm{z}$ niewielu jakie powstały $\mathrm{w}$ tamtym okresie, niekoniecznie musi "zajmować się pewnymi problemami i ich rozwiązywaniem w życiu prawnym (ustawodawstwie) i nauce"29. Niemniej jednak trafne jest spostrzeżenie recenzenta, że „filozofia to nie czcza i pusta gadanina, igraszka idei czy projektów. Tu chodzi o ujęcie danej - czy całej rzeczywistości w jej właściwym kierunku

\footnotetext{
${ }^{22}$ Idem, Teoria prawa, s. 4.

${ }^{23}$ Idem, Historia filozofii prawa, Warszawa 1923, s. 1.

${ }^{24}$ Zob. ibidem Przedmowa, s. V.

${ }^{25}$ Ibidem, s. VI.

${ }^{26}$ Idem, Historia filozofii prawa, s. 2 i 3.

${ }^{27}$ E. Bautro, Recenzja pracy E. Jarry: Historia filozofii prawa, „Kwartalnik Filozoficzny” 1923, rok I,

${ }^{28}$ Ibidem, s. 120.

${ }^{29}$ Ibidem, s. 125.
} z. 1 , s. 120 . 
i przedmiocie" ${ }^{30}$. Ujęciem aktualnej rzeczywistości prawnej powinna bowiem zajmować się nauka prawa, czyli prawoznawstwo, filozofia zaś powinna ujmować przyszłą rzeczywistość prawną - dociekając jej w drodze logicznego rozumowania, a nie na podstawie danych z rzeczywistości.

Zupełnie inaczej pracę E. Jarry w swojej recenzji ocenił Cz. Znamierowski, który twierdził, że dla niego filozofia jest właśnie taką „czczą i pustą gadaniną”, tak jak mówienie o przyszłym prawie i jego projektach ${ }^{31}$. Za niebezpieczne uważał traktowanie filozofii prawa jako nauki zajmującej się „przyszłą rzeczywistością prawa”. Z E. Bautro zgodził się jedynie w kwestii mało precyzyjnych definicji pojęć u E. Jarry, ale całą Historię filozofii prawa ocenił ostatecznie jako bardzo pożyteczną propozycję nowego podręcznika.

\section{Teoria prawa natury}

Eugeniusz Jarra rozpatrywał swoje zagadnienia dotyczące społecznej genezy przeżyć prawnych w szerszym kontekście ogólnych rozważań socjologicznych. Nietrudno było w nich dostrzec wpływy różnorodnych koncepcji zarówno psychologizmu socjologicznego, jak i socjologii formalnej ${ }^{32}$. Szczególnie widoczne było to przy analizie teorii społeczeństwa ujmowanego w najszerszym znaczeniu jako „ogół związków zależności wzajemnej i tegoż oddziaływania na siebie, ludzi oraz innych z nimi, według ich mniemania obcujących bytów [...]"33. Jednakże chodzi tutaj przede wszystkim o międzyludzkie zależności i oddziaływania (stosunki) stanowiące istotę społeczeństwa, które jest nie tylko ogółem tych stosunków, ale i ich organizacją ${ }^{34}$. Związane z tym trudności dotyczyły najczęściej asymilacji poszczególnych idei pochodzących z odmiennych koncepcji socjologicznych, których wyboru E. Jarra dokonywał w taki sposób, że jego własne koncepcje stawały się często niespójne i niezrozumiałe. Sytuację komplikował dodatkowo fakt występowania w przeprowadzanej przez niego analizie społecznej przeżyć prawnych - licznych wątków prawnonaturalnych ${ }^{35}$. E. Jarra traktował je jako postulaty wobec organów ustawodawczych i chociaż zgodnie z teoriami prawa natury o zmiennej treści nie wyrażały one absolutnie niezmiennych norm, to jednak odgrywały doniosłą rolę w społeczeństwie ${ }^{36}$. Podstawą kształtowania się społeczeństw był naturalny „instynkt ładu”, gdyż ludzie mają w sobie natural-

\footnotetext{
${ }^{30}$ Ibidem, s. 123.

${ }^{31}$ Por. Cz. Znamierowski, Recenzja pracy E. Jarry: Historia filozofii prawa, „Ruch Prawniczy i Ekonomiczny" 1924, rok IV, nr 3, s. 395-397.

${ }^{32}$ Por. S. Czepita, Koncepcje teoretycznoprawne w Polsce..., s. 116.

${ }^{33}$ E. Jarra, Ogólna teoria prawa..., s. 47 i n.

${ }^{34}$ Ibidem, s. 48 i n.

${ }^{35}$ Por. S. Czepita, Koncepcje teoretycznoprawne w Polsce..., s. 116.

${ }^{36}$ Por. M. Szyszkowska, Teorie prawa natury..., s. 121.
} 
ne skłonności do przeżywania powinności określonych zachowań niezbędnych dla utrzymania w zbiorowości, w których żyją - porządku i ładu ${ }^{37}$. „Poczucie ładu” jest dla trwałego współżycia ludzi czynnikiem rozstrzygającym, ponieważ „dzięki niemu psychika istoty społecznej zawiera specjalny impuls, warunkujący wszelki byt wspólnoty, a znajdujący swój wyraz i ziszczenie w sposobach i środkach, za pomocą których człowiek zbiorowy dąży do urzeczywistnienia tych czy innych celów"38. Zgodnie z założeniami filozofii Kanta - powinność sprawia, iż człowiek wchodzący we wspólnotę ma dwa ściśle ze sobą związane obowiązki: założenia jej na podstawie umowy oraz utrzymanie za pomocą prawa, które ma być czynnikiem umożliwiającym zaprowadzenie ładu w społeczeństwie ${ }^{39}$. Przeżycia powinności określonych zachowań oparte na naturalnych skłonnościach nazwał E. Jarra - normami postępowania ${ }^{40}$.

Z kolei normy prawne, które są szczególnego rodzaju normami postępowania, określił jako „te wyobrażenia, które dzięki psychice prawnej danego środowiska istnieją u jego członków w związku z określonymi faktami, otrzymującymi przez to charakter faktów normatywnych" ${ }^{41}$. Tak ujmowane pojęcie normy zawsze należy rozpatrywać w związku z pojęciem społeczeństwa. Jednakże związek społeczno-państwowy nie może rozstrzygać o istocie prawa ${ }^{42}$. Autorytetu prawa należy zatem szukać w psychice ludzkiej jako psychice człowieka społecznego oraz jego poczuciu ładu ${ }^{43}$.

Metoda krytyczna zastosowana w nauce prawa doprowadziła według E. Jarry do powstania antytezy dwóch porządków prawnych, czyli dualizmu prawnego jaki zachodził między prawem obowiązującym a prawem idealnym (naturalnym) ${ }^{44}$. Tęsknota za prawem idealnym budziła zawsze myśl krytyczną, stwarzając przy tym postulaty nowego porządku, oddając przez to nieocenione usługi postępowi prawa we wszystkich jego dziedzinach. Prawo naturalne, będące ideałem prawa pozytywnego, nigdy nie przestało istnieć w filozofii prawa, czy to jako prawo o treści określonej i niezmiennej, czerpanej z Boskiego Objawienia, czy jako prawo natury o zmiennej treści, czyli „jako tylko stale stawiany

${ }^{37}$ S. Czepita, Koncepcje teoretycznoprawne w Polsce..., s. 116; zob. R. A. Tokarczyk, Prawo natury jako uniwersalna podstawa ładu społecznego, [w:] Filozofia prawa a tworzenie i stosowanie prawa, red. B. Czech, Katowice 1992, s. 189-202.

${ }^{38}$ E. Jarra, Ogólna teoria prawa..., s. 134.

${ }^{39}$ Por. E. Nowak-Juchacz, Immanuela Kanta droga do republikanizmu, [w:] Filozofia a demokracja, red. P. W. Juchacz, R. Kozłowski, Poznań 2001, s. 76 i n.; A. Kryniecka, Kantowska apologia prawa jako czynnika umożliwiającego zaprowadzenie ładu w społeczeństwie, [w:] Silne państwo, red. M. Szyszkowska, Białystok 1999, s. 227-230.

${ }^{40}$ Por. S. Czepita, Koncepcje teoretycznoprawne w Polsce..., s. 116-117.

${ }^{41}$ E. Jarra, Ogólna teoria prawa..., s. 205.

${ }^{42}$ Idem, Historia filozofii prawa..., s. 2.

${ }^{43}$ Idem, Teoria prawa, s. 25.

${ }^{44}$ Por. idem, Ogólna teoria prawa..., s. 25 i n. 
postulat formalny rozumu ludzkiego, który każda epoka kulturalna własną wypełnia treścią" ${ }^{45}$. W tym drugim przypadku, wykorzystującym metodę krytyczno-filozoficzną do poszukiwania prawa idealnego, widać wyraźnie wpływ kantowskiej filozofii krytycznej zastosowanej na gruncie teorii prawa. W obydwu przypadkach prawo natury (naturalne) nie ma nic wspólnego z prawami przyrody. Jednak w dziedzinie normatywnej jest ono podstawą pożądanego systemu prawnego przeciwstawianego systemowi prawa pozytywnego ${ }^{46}$. Już w nauce św. Pawła i św. Augustyna o prawie naturalnym rozum był tego prawa zwiastunem, a istota rozumna, niczym u Kanta, staje się własnym ustawodawcą i kierownikiem, bo z jej natury wypływa ogół najwyższych zasad. Dla Kanta każdy osobnik będący jednostką wolną i rozumną jest sam sobie autonomicznym źródłem norm postępowania moralnego jako zdolności woli do ustanawiania powinności (das Sollen) wyprowadzanych z czystego rozumu praktycznego ${ }^{47}$. Prawo naturalne, którego źródłem jest natura ludzka, obejmuje zarówno rozum jak i wolę, przy czym naczelną rolę przyznaje jednak rozumowi, który nie tylko wskazuje normę tego prawa, ale także kieruje wolą ${ }^{48}$.

Powyższe wnioski E. Jarry są o tyle istotne, iż dopiero teorie prawa natury o zmiennej treści, stworzone pod koniec XIX w., uznały rozum za źródło tego prawa, o którym jak widać mówiło się już od wieków ${ }^{49}$.

Kantowska nauka prawa składa się z dwóch części: dotyczącej „prawa pozytywnego, obowiązującego $\mathrm{z}$ woli ustawodawcy, oraz jego sprawdzianu prawa naturalnego, zawartego w pierwiastkowych zasadach świadomości, a stąd obowiązującego mocą swej zgodności z rozumem, przez który jest odkrywany" ${ }^{50}$.

Zdaniem E. Jarry, prawo natury $w$ tej czy innej postaci jest przejawem właściwości psychicznej człowieka niezadowolonego z rzeczywistości, ale z tendencjami do wyzwolenia się z tej rzeczywistości ${ }^{51}$. Pojęcie prawa natury o zmiennej treści otworzyło nowy okres w dziejach filozofii prawa, zwany „odrodzeniem prawa naturalnego" ${ }^{\prime 2}$. Co ciekawe, za głównego przedstawiciela tego kierunku uznał on nie Leona Petrażyckiego, lecz niemieckiego neokantystę Rudolfa Stammlera, którego filozofia prawa stanowiła przykład zastosowania w prawoznaw-

${ }^{45}$ Idem, Teoria prawa, s. 5-6.

${ }^{46}$ Idem, Socjologia katolicka, s. 31-42.

${ }^{47}$ Ibidem, s. 37.

${ }^{48}$ Ibidem, s. 35.

${ }^{49}$ Dopiero od 1896 r. uznaje się rozum za źródło prawa natury o zmiennej treści, o czym w swoich koncepcjach pisali zarówno L. Petrażycki, jak i R. Stammler. Ten pierwszy krytykował jednak kantowską teorię prawa, drugi zaś na niej bazował; zob. M. Szyszkowska, Europejska filozofia prawa, Warszawa 1993, s. 66 i n.; Zarys filozofii prawa, Białystok 1994, s. 30-31 oraz 155-170; Zarys europejskiej filozofii prawa, Białystok 2004, s. 17, 78-79 i 192-204.

${ }^{50}$ E. Jarra, Socjologia katolicka, s. 37.

${ }^{51}$ Por. idem, Ogólna teoria prawa..., s. 30.

${ }^{52}$ Ibidem, s. 29. 
stwie filozoficznych rozwiązań Kanta ${ }^{53}$. W powyższym kontekście „prawo natury o zmiennej treści, to jest powszechność stawiania sprawdzianu doskonałości, względność natomiast $\mathrm{w}$ pojmowaniu jego treści, zależnej od tych czy innych warunków" ${ }^{34}$. Bez istnienia w naturze ludzkiej idei prawa nie mogła powstać moc obowiązująca pierwszego zwyczaju, ani pierwszej ustawy, które idea ta poprzedza, dla których jest wzorem i probierzem ${ }^{55}$. Poza dziedziną filozofii prawa - prawo natury można spotkać $\mathrm{w}$ aktach prawnych, w których powołane bywa jako doskonała i właściwa modła dla stosunków ludzkich w pełnym ich zakre$\operatorname{sie}^{56}$. Daje ono o sobie znać w praktycznym zastosowaniu, jako że: „wiele ustaw $\mathrm{w}$ nim znalazło pobudkę, wiele reform społecznych z niego wzięło początek i jego ideały święciły wielokrotnie tryumf wkroczenia przez recepcje do prawa pozytywnego, jak np. przy zniesieniu niewolnictwa, równouprawnieniu kobiet, obronie pracy, usuwaniu segregacji rasowej. w jego imieniu walczą narody o niepodległy byt państwowy" ${ }^{\prime \prime}$. W życiu codziennym, kierowanym zdrowym rozsądkiem, każdy człowiek - zdaniem E. Jarry - nie myśląc o prawie naturalnym, podąża jednak żywiołowo śladami wyznaczonych przez niego nakazów ${ }^{58}$. W pojęciu prawa naturalnego i jego poszczególnych zasadach ukrywa się pod zasłoną filozoficznej konstrukcji naukowej powszechne i zwykłe źródło praktycznej mądrości życiowej, której przejawem jest „intuicyjne wyczuwanie potrzeb życia prawnego, występujące pod postacią głosu słuszności”59.

Eugeniusz Jarra utożsamiał więc słuszność z prawem natury, ponieważ pod względem treści ich normy przeciwstawiane porządkowi prawa pozytywnego były w zasadzie identyczne ${ }^{60}$. Głos słuszności uznawał on, podobnie jak prawo natury, za głos imperatywno-atrybutywnej, autonomicznej psychiki ludzkich grup i jednostek, stanowiący „ogół warunków kulturalnych, wśród których się dany podmiot znajduje, oraz tego podmiotu cech wyłącznie indywidualnych [...]"61. W Teorii prawa z 1942 r. E. Jarra dodał, że słuszność różni się od prawa stanowionego, gdyż jest autonomicznym poglądem psychiki danej jednostki na indywidualne znaczenie danego czynu czy stanu. Słuszność różni się również od sprawiedliwości, która jest jedynie cnotą, należy do sfery moralności i jako pewnego rodzaju ideał stanowi doskonały, ale nieziszczalny cel prawa. W prze-

${ }^{53}$ Zob. R. Stammler, Wirtschaft und Recht nach der materialistischen Geschichtsauffassung, Leipzig 1914; Die Lehre von dem richtigen Recht, Berlin 1902; Theorie der Rechtwissenschaft, Halle 1911; por. P. Janet, Historia doktryn politycznych wraz z historia filozofii prawa, tłum. E. Rutkowska, Poznań 1923, s. 195-196.

${ }^{54}$ E. Jarra, Ogólna teoria prawa..., s. 29-30.

${ }^{55}$ Por. idem, Socjologia katolicka, s. 35-36; Powołanie prawników..., s. 43-44.

${ }^{56}$ Idem, Teoria prawa, s. 5-6.

${ }^{57}$ Idem, Powołanie prawników..., s. 44 i 45.

${ }^{58}$ Por. ibidem, s. 43.

${ }^{59}$ Idem, Ogólna teoria prawa..., s. 204.

${ }^{60}$ Por. ibidem, s. 204.

${ }^{61}$ Ibidem, s. 180 oraz 197 i n. 
ciwieństwie do sprawiedliwości - słuszność powinna w prawie znajdować jak najpełniejszą realizację, jako że tylko udoskonalane przez słuszność prawo jest w stanie zbliżyć się do jej absolutnych wymagań ${ }^{62}$.

\section{Prawo a moralność}

Rozważając stosunki zachodzące między prawem i moralnością, E. Jarra wyróżniał: sferę odrębną, w której zachodzi rozgraniczenie prawa od moralności oraz sferę identyczną - zgodności przepisów prawa i moralności; następnie sferę, w której prawo jest jedynie wycinkiem moralności oraz istnienia sfery wspólnej i różnej zarazem, gdzie mogą występować zarówno prawnie obojętne przepisy moralne, jak i moralnie obojętne przepisy prawne ${ }^{63}$. Nie jest więc tajemnicą, że Kanta zaliczył on do sfery pierwszej, a dokonany przez niego rozdział sfer prawa i moralności sprowadza się do tego, iż nauka prawa i moralności, choć czerpią ze wspólnego źródła jakim jest rozum ${ }^{64}$, różnią się od siebie nie tyle właściwymi dla każdej obowiązkami, ile raczej wchodzącymi w grę tu i tam pobudkami czynów z nimi związanych ${ }^{65}$. Według E. Jarry, istotną cechą każdej normy społecznej jest obowiązek, któremu jeśli nie odpowiada niczyje roszczenie, to związane z nim normy nazywa się jednostronnymi. Natomiast jeśli obowiązkowi odpowiadają czyjeś roszczenia, to normy takie nazywa on dwustronnymi ${ }^{66}$. Normy moralne mają jedynie charakter jednostronny, normy prawne zaś dwustronny, czyli imperatywno-atrybutywny. Podobnie jest ze słusznością, która będąc również normą dwustronną, dotyczy najczęściej tych samych co i prawo przedmiotów, lecz ujmowanych ze względu na decydującą dla niej indywidualną psychikę ludzką ${ }^{67}$. Prawo to normy działające zewnętrznie, dla których najważniejsza jest zgodność stanu rzeczy z jego przepisem, czyli legalizm. Za legalność E. Jarra uznawał „zewnętrzną, bez względu na pobudki, zgodność czynu z przepisem, której motywem może być coś zupełnie innego, niż przepis, np. strach; za moralność zaś taką zgodność postępowania z przepisem, przy której motywem jest idea przepisanego obowiązku, czyli że spełnia się go dla niego samego"68. Ze stanowiska prawnego obojętne jest według jakich pobudek na przykład dłużnik spłacił dług, ważne jest, że go spłacił. W moralności natomiast, której normy działają wewnętrznie,

${ }^{62}$ Por. idem, Teoria prawa, s. 31-32.

${ }^{63}$ Ibidem, s. 29 i n.; Ogólna teoria prawa..., s. 125-128 oraz 187-195; zob. A. Breczko, Prawo a moralność w teorii i praktyce. Wczoraj i dziś (Zarys wykładu), Białystok 2004, s. 29 i n.

${ }^{64}$ Por. I. Kant, Die Metaphysik der Sitten, Berlin 1922, s. 31.

${ }^{65}$ Por. E. Jarra, Historia filozofii prawa, s. 172; Ogólna teoria prawa..., s. 189.

${ }^{66}$ Idem, Teoria prawa, s. 18-19.

${ }^{67}$ Idem, Ogólna teoria prawa prawa..., s. 200.

${ }^{68}$ Idem, Socjologia katolicka, s. 53; por. Z. Tobor, Pojęcie legalności w filozofii Immanuela Kanta, „Folia Philosophica”, z. 15, red. J. Bańka, Katowice 1997, s. 121-133. 
wymagając przy tym odpowiedniego usposobienia i przekonania ${ }^{69}$ - to pobudki i motywy decydują w zasadzie o wartości moralnej każdego postępowania ${ }^{70}$. W powyższym kontekście okoliczności zewnętrzne mają dla moralności znaczenie tylko wtedy, gdy wywierają wpływ na stan wewnętrzny jednostki lub są tego stanu wyrazem ${ }^{71}$.

W Socjologii katolickiej E. Jarra stanął zdecydowanie po stronie nauki Kościoła, uznając za sztuczne przeciwstawienie moralności prawu oraz dokonanie przez Kanta podziału na prawo pozytywne i naturalne, bez powiązania tego $\mathrm{z}$ wyższym rozumem. Jego zdaniem, „nauka katolicka w przeciwieństwie do Kanta, widzi, jak już wiadomo, w poznaniu nie tylko pierwiastkową, aprioryczną właściwość myśli, lecz i rezultat doświadczenia zmysłowego. Według tego stanowiska rozum może wznieść się ponad empirię i stwierdzać prawo, władnące światem. W zakresie etyki Kant zapoznaje, że człowiek nie stwarza swym rozumem idei moralnych, podobnież jak w ogóle nie stwarza prawdy, tylko ją znajduje w istniejącym niezależnie obiektywnym porządku rzeczy. Autonomia człowieka $\mathrm{w}$ sensie chrześcijańskim polega na tym, że rozum poznaje treść zakonu wiecznego i czyni ją obowiązkiem woli. Nie przeczy to godności ludzkiej, chodzi bowiem o poddanie się prawu własnej rozumnej natury, nie zaś przepisowi obcemu, narzuconemu; a wszakże i Kant podporządkowuje moralną wolę jednostki nie jej rozumowi indywidualnemu, lecz czystemu, czyli jakiemuś powszechnemu, koniecznemu [...]"72.

Można powiedzieć, iż traktowanie dorobku Kanta przez E. Jarrę było wybiórcze i zależało właściwie od tego, jak miało się do nauki Kościoła rzymskokatolickiego. Powyższe stanowisko uczonego potwierdza dodatkowo inna jego powojenna praca pt. Człowiek a władza z 1947 r. Eugeniusz Jarra uznał w niej godność człowieka za ogół cech i właściwości moralnych, które tak jak u Kanta stanowią jego wartość wewnętrzną ${ }^{73}$, bezwzględną oraz niezależną od czasu i przestrzeni ${ }^{74}$. Godność człowieka wypływa z istoty człowieka i stanowi przyrodzone mu prawo ${ }^{75}$. Nie ma więc sprzeczności między tak rozumianą godnością człowieka a jego przyrodzonym prawem, w znaczeniu prawa natury ${ }^{76}$.

${ }^{69}$ Por. E. Jarra, Teoria prawa, s. 21 i 23.

${ }^{70}$ Por. G. Mohr, Etyka Kanta. Wprowadzenie, tłum. M. Potępa, [w:] Dwieście lat z filozofią Kanta, red. M. Potępa, Z. Zwoliński, Warszawa 2006, s. 197; Z. Tobor, Pojęcie legalności w filozofii..., s. 123; A. Niemczuk, Wolność egzystencjalna. Kant i Kierkegaart, Lublin 1995, s. 227; D. Scott-Kakures, S. Castagnetto, H. Benson, W. Taschek, P. Hurley, Wstęp do historii filozofii, tłum. J. Ruszkowski, Poznań 1999, s. 287 i 289.

${ }^{71}$ E. Jarra, Teoria prawa, s. 21.

${ }^{72}$ Idem, Socjologia katolicka, s. 38.

${ }^{73}$ Por. I. Kant, Metafizyczne podstawy nauki o cnocie, tłum. W. Galewicz, Kęty 2005, s. 107 i n.

${ }^{74}$ E. Jarra, Człowiek a władza, s. 1.

75 Zob. K. Kuźmicz, Prawa człowieka i ich kantowskie inspiracje, [w:] Filozofia Kanta w XXI wieku, red. M. Szyszkowska, Warszawa 2005, s. 125 i n.

${ }^{76}$ Por. E. Jarra, Człowiek a władza, s. 1. 


\section{Kantowskie inspiracje idei jedności obywatelskiej}

Ostatnią rzeczą, na którą warto jest zwrócić uwagę, doszukując się kantowskich inspiracji w poglądach filozoficznoprawnych E. Jarry, jest zagadnienie jedności obywatelskiej, które rozważał on na przestrzeni dziejów filozofii prawa. Według niego idea ta należy do rzędu najwcześniejszych i najpopularniejszych w dziejach, gdyż poświęcali jej uwagę wszyscy najwybitniejsi filozofowie i myśliciele polityczni ${ }^{77}$. Na pytanie, gdzie szukać genezy i źródła idei jedności obywatelskiej, która zajmuje zdaniem E. Jarry doniosłe miejsce nie tylko w historii, ale także w doktrynie i ustrojach państw współczesnych - odpowiada on, że w teorii solidaryzmu. Jednakże posiada ona przeszłość dawniejszą i pocześniejszą niż solidaryzm, gdyż zrodziła się już w starożytnej Grecji. Jej elementy można również dostrzec w dziejach polskiej myśli politycznej, a nawet w rozwiązaniach ustrojowych Polski mu współczesnej, czego wyrazem była konstytucja kwietniowa z 1935 r. W jej artykule 9 Polska jako państwo proklamowała jedność obywatelską, ponieważ „dąży do zespolenia wszystkich obywateli w harmonijnym współdziałaniu na rzecz dobra powszechnego"78.

Postulat dobra powszechnego wysuwał wielokrotnie także J. Piłsudski oraz przedstawiciele doktryny uniwersalizmu, wiążący go właśnie z ideą jedności obywatelskiej $^{79}$. Podobny pogląd reprezentował - zdaniem E. Jarry - Wacław Makowski, który poszukiwał formy ustroju zdolnej przeciwstawić się tendencjom „decentralizującego, wybujałego indywidualizmu”, znajdując ją w „zasadach unifikacyjnych solidaryzmu społecznego" ${ }^{80}$. Z kolei główny rzecznik tego kierunku G. del Vecchio pisał, że państwo nowoczesne jest wyrazem dyscypliny oraz zgody cywilnej obywateli (concordia civile) i powinno realizować całkowicie jedność moralną, polityczną i ekonomiczną narodu ${ }^{81}$. Prawo w takim państwie rozciąga swe władztwo na wszystkie formy życia, nie wyłączając także tych, które przez nieporozumienia liberalizmu pozostają w stanie półanarchii ${ }^{82}$. Twórcy konstytucji polskiej uzasadniali jednak, że poszli własną drogą, szukając „syntezy pomiędzy indywidualizmem, głęboko zakorzenionym w duszy Narodu Polskiego, a doświadczeniami zaczerpniętymi z naszych dziejów"83. Doświad-

${ }_{77}$ Idem, Jedność obywatelska $w$ dziejach filozofii prawa, odbitka z „Themis Polska”, t. IX, Warszawa 1937, s. 63.

${ }^{78}$ Konstytucja Rzeczypospolitej Polskiej z 23 kwietnia 1935 roku, Dz. U.R. P. Nr 30, poz. 227.

${ }^{79}$ E. Jarra, Jedność obywatelska..., s. 3 i 5.

${ }^{80}$ Ibidem, s. 2; zob. W. Makowski, La nova constituzione polacca, „La Stato”1935, IV, s. 6; idem, Constitution de la République de Pologne du 23 avril 1935, Varsovie 1935, s. 10; idem, Państwo społeczne, Warszawa 1936, s. 63.

${ }^{81}$ Zob. G. del Vecchio, La crisi dello Stato, „Rivista Internazionale di Filosofia del Diritto” 1933, s. 13 i 20-27; Stato e corporazione, „Rivista Internazionale di Filosofia del Diritto” 1934, s. 32.

${ }^{82}$ E. Jarra, Jedność obywatelska..., s. 1 i 2.

${ }^{83}$ S. Car, Idee przewodnie nowej Konstytucji, [w:] S. Car, B. Podoski, Główne wytyczne nowej Konstytucji Rzeczypospolitej Polskiej, Warszawa 1935, s. 28. 
czenia te, jak wskazywał E. Jarra, były związane z rozwiązaniami ustrojowymi Włoch Mussoliniego i hitlerowskich Niemiec ${ }^{84}$. Wysuwane przez faszyzm i narodowy socjalizm postulaty jedności obywatelskiej czy narodowej (rasowej) - dały jego zdaniem - z jednej strony słuszną podstawę do uznania za główny ich cel praktyczny walki z wszelkimi dążeniami rozsadzającymi państwo, z drugiej zaś strony totalizm polityczny został uznany w tych państwach za cel najwyższy, zarówno nauki, jak i praktyki prawnej ${ }^{85}$.

Zdaniem E. Jarry, „uniwersalizm dzisiejszy, stawiając całość nad jednostką nie uważa tego bynajmniej za jej ofiarę, za jej unicestwienie; utrzymuje bowiem, że skoro jednostka może istnieć tylko w społeczności i przez społeczność, to nie może jej składać czegokolwiek w ofierze [...]. Nie może być mowy o ofierze na rzecz całości ze strony jednostki, która będąc jako część całości wystawiona na niebezpieczeństwo, występuje tylko we własnej obronie" ${ }^{36}$. Tak rozumiany uniwersalizm znalazł swój wyraz w propagowanym przez zwolenników konstytucji kwietniowej haśle: „wolny obywatel w silnym państwie” ${ }^{87}$.

Z dzisiejszej perspektywy można powiedzieć, że E. Jarra bardzo pomylił się w swoich ocenach dotyczących rozwiązań praktycznych (ustrojowych) obu polityczno-prawnych doktryn. W tym konkretnym przypadku, związanym z ideą jedności obywatelskiej, mylił się on również interpretując filozofię Kanta. Jej uniwersalistyczne stanowisko uwydatnia się szczególnie w nauce o jedności obywatelskiej, która jest aprioryczną ideą rozumu, zakładającą, iż w stanie bezprawnym (naturalnym) zarówno jednostki, jak i narody, czy nawet państwa, nie mogą być w pełni zabezpieczone przeciwko zadawanym sobie gwałtom ${ }^{88}$. Miał jednak rację E. Jarra, gdy twierdził, że w koncepcji Kanta państwo jako korelat prawa jest koniecznym warunkiem triumfu idei prawa oraz gdy w jego racjonalistycznym systemie dostrzegał nieścisłość, pisząc, że swoboda obywateli nie odpowiada jej znaczeniu w stosunkach rzeczywistego doświadczenia prawnego ${ }^{89}$. Państwo, które ma odpowiadać kantowskim wymaganiom etycznym i traktować człowieka jako cel sam w sobie, to tzw. idealne państwo celów. Stanowi ono całość powstałą na podstawie apriorycznej idei umowy społecznej, godząc za

${ }^{84}$ E. Jarra przywołuje tutaj najpierw hasło Mussoliniego: „Wszystko dla państwa, nic przeciw państwu, nic poza państwem”, a następnie cytuje Mein Kampf Hitlera: „Państwo jest środkiem do celu. Cel jego polega na utrzymaniu i popieraniu wspólnoty istot, jednakich fizycznie oraz duchowo”. Różnica według E. Jarry między narodowo-socjalistycznymi Niemcami a faszystowskimi Włochami, które dążą do jedności obywatelskiej, sprowadza się do tego, że ci pierwsi za wyraziciela i rzecznika tej idei uznają naród, a nie państwo; zob. B. Mussolini, La dottrina del Fascismo, Roma 1934, s. 6, 8 i 22; A. Menzel, Der Staatsgedanke des Faschismus, Berlin 1935, s. 56.

${ }^{85}$ E. Jarra, Jedność obywatelska..., s. 4.

${ }^{86}$ Ibidem, s. 3.

${ }^{87}$ Por. S. Car, Idee przewodnie..., s. 31.

${ }^{88}$ Por. E. Jarra, Jedność obywatelska..., s. 49.

${ }^{89}$ Por. idem, Historia filozofii prawa, s. 175. 
pomocą prawa indywidualną wolność każdego z wolnością wszystkich innych ${ }^{90}$. Wyraźny wpływ Rousseau na Kanta doprowadził, zdaniem E. Jarry, do przyjęcia przez tego drugiego fikcji nadempirycznej woli ogółu i takiejże woli jednostki, doprowadzając „do wniosku, że najbardziej absolutna władza państwa nie sprzeciwia się swobodzie jednostki, będąc tylko jej własnej woli wyrazem. Uznanie istnienia państwa za nakaz rozumu sprawiło, iż władzę państwową ogłoszono za nieomylną: obywatele winni są jej posłuszeństwo bez zastrzeżeń i za przestępstwo karane śmiercią lub wygnaniem zostaje uznane nie tylko jawne przeciwko niej wystąpienie, lecz nawet powątpiewanie o jej słuszności oraz bierny w stosunku do niej opór"91. Tak rozumiane państwo, będące zarazem jednością wła$\mathrm{dzy}^{92}$, ma przede wszystkim troszczyć się o racjonalny porządek prawny i czuwać nad wypełnianiem przez obywateli ustalonych w prawie obowiązków ${ }^{93}$.

W powyższym kontekście okazuje się, że jedność obywatelska uznana przez Kanta za podwalinę państwa może być przez nie realizowana nawet środkami przymusowymi i policyjnymi. Ma to być jednak usprawiedliwione powszechnym interesem wszystkich, którym służy ogół stosunków obywatelskich, związanych w państwo ${ }^{94}$. „Skoro zaś stanowisko, określające się prawami bez współrzędnych im obowiązków oraz stosowaniem siły bez ulegania jej, posiada sam tylko Bóg, to wyposażone u Kanta w powyższe atrybucje państwo zostaje przezeń uznane za wcielenie idei Boskiej"95. Interpretacja państwa zaproponowana przez E. Jarrę doprowadziła do kontrowersyjnego stwierdzenia, iż „system prawny III Rzeszy zainspirowany był teorią Kanta"96. Nie ulega wątpliwości, że w sposób sensowny nie mogą tego udowodnić ci, którzy stawiają Kantowi zarzut, że jego idee miały merytoryczny związek z ideologią totalitarną ${ }^{97}$. Jak zauważa współczesny historyk filozofii F. Copleston - Kant „nie był tego typu myślicielem, z którego naziści mogliby czerpać”98. Podobnie uważał K. R. Popper, uznający myśliciela z Królewca za głównego filozofa antytotalitarnego i obrońcę tzw. społeczeństwa otwartego, który tak jak Sokrates walczył o wolność jako „jedyną wartościową

${ }^{90}$ Por. I. Kant, Metafizyczne elementy teorii prawa, tłum. Cz. Tarnogórski, [w:] M. Szyszkowska, Zarys filozofii..., s. 220.

${ }^{91}$ E. Jarra, Historia filozofii prawa, s. 176.

${ }^{92}$ Idem, Jedność obywatelska..., s. 50.

${ }^{93}$ Por. Z. Kuderowicz, Praworządność a demokracja. Dylematy filozofii politycznej w Niemczech przełomu XVIII i XIX wieku, [w:] Filozofia a demokracja..., s. 52.

${ }^{94}$ Por. E. Jarra, Jedność obywatelska..., s. 50.

${ }^{95}$ Idem, Historia filozofii prawa, s. 176.

${ }^{96}$ M. A. Krąpiec, Filozofia prawa, [w:] Powszechna encyklopedia filozofii, t. 3, M. A. Krąpiec (przew. Kom. Nauk.), Lublin 2002, s. 509.

${ }_{97}$ S. Gałkowski, Kant i totalitaryzm? [w:] Kant wobec problemów wspótczesnego świata, red. J. Miklaszewska, P. Spryszak, Kraków 2006, s. 97.

${ }_{98}$ F. Copleston, Historia filozofii, t. 6, Od Wolffa do Kanta, tłum. J. Łoziński, Warszawa 1996, s. 202. 
formę ludzkiego życia" ${ }^{\prime 9}$. Zgodzić się jednak trzeba z poglądem zakładającym, iż sposób w jaki uprawiał Kant swoją filozofię, a zwłaszcza etykę, może stanowić wzorzec, do którego łatwo dopasować myślenie utopijne i fanatyczne ${ }^{100}$. Łatwo wówczas interpretować ją powierzchownie i w sposób wybiórczy, wykorzystując często do doraźnych celów.

Faktem jest, że filozofię Kanta można uznać za filozofię wyrażającą ideę jedności obywatelskiej w państwie, ale nie można tego czynić bez jednoczesnego uwzględnienia takich idei, jak chociażby: wolność, wieczny pokój, republikanizm oraz państwo celów. Czym innym bowiem jest idea np. państwa celów, a czym innym samo państwo jako zjednoczenie istot rozumnych pod władzą wspólnych ustaw, którego obywatele mają obowiązek szacunku dla prawa ${ }^{101}$. Zgodnie z kantowską etyką deontologiczną (powinnościową), obowiązek przestrzegania prawa wiąże się zawsze $\mathrm{z}$ szacunkiem dla człowieczeństwa i godności ludzkiej, tkwiącej w każdej istocie rozumnej, wolnej i moralnej zarazem - uznawanej za wartość najwyższą. Bezwzględny charakter imperatywu kategorycznego ma sens tylko wtedy, gdy uzupełniamy go imperatywem praktycznym i koniecznością tratowania każdego człowieka jako „celu samego w sobie” ${ }^{102}$. Państwo, które tego nie robi, nie może powoływać się na zgodność z filozofią Kanta, nawet jeśli jego obywatele przestrzegają prawa dla samego prawa. Powołując się przy tym na swój obowiązek, nigdy nie mogą oni traktować innych ludzi jako jedynie środków. W tym ostatnim przypadku kantowski imperatyw praktyczny ma decydujące znaczenie.

\section{Wnioski}

Jako historyk filozofii prawa E. Jarra nie przypisywał systemowi filozofii kantowskiej szczególnego miejsca. Nie był z pewnością kantystą ani neokantystą, a jednak często odwoływał się do filozofii Kanta. Zwłaszcza w poglądach filozoficznoprawnych wpływ Kanta i jego filozofii jest widoczny, co nie oznacza, że we wszystkich kwestiach podzielał on stanowisko królewieckiego myśliciela. Inspiracje kantowskie E. Jarry mają charakter pośredni, ponieważ nie stworzył on żadnej pracy bezpośrednio odwołującej się do filozofii krytycznej. Doceniał jednak jej wkład nie tylko w dziejach ogólnej filozofii, ale także historii filozofii prawa, do której się odwoływał, badając i poszukując idei leżących zarówno

${ }_{99}$ K. R. Popper, W poszukiwaniu lepszego świata. Wykłady i rozprawy z trzydziestu lat, tłum. A. Malinowski, Warszawa 1997, s. 160; zob. idem, Społeczeństwo otwarte i jego wrogowie. Wysoka fala proroctw: Hegel, Marks i następstwa, t. 2, tłum. A. Krahelska, Warszawa 1993.

100 S. Gałkowski, Kant i totalitaryzm? s. 97.

101 Por. I. Kant, Uzasadnienie metafizyki moralności, tłum. M. Wartenberg, Warszawa 1984, s. 68 i n.

102 Ibidem, s. 73-75 i 110; idem, Krytyka praktycznego rozumu, tłum. J. Gałecki, Warszawa 1972, s. 144,180 i 211 . 
u podstaw prawa naturalnego i stanowionego jako wewnętrzny głos słuszności czy sprawiedliwości.

Stanowisko filozoficznoprawne E. Jarry składa się w zasadzie z różnych koncepcji, wśród których na pierwszym miejscu należy jednak wymienić jako dominującą filozofię chrześcijańską i opartą na niej naukę społeczną Kościoła katolickiego. Jednakże podejście do kwestii prawa naturalnego, zwłaszcza w okresie międzywojennym, stawia go wśród zwolenników teorii tegoż prawa o zmiennej jego treści. Ważne miejsce zajmuje też jego podejście do relacji zachodzących między prawem i moralnością oraz tego, że normy prawne mają w przeciwieństwie do norm moralnych dwustronny charakter, czyli atrybutywno-dystrybutywny, co wiąże je o wiele ściślej niż moralność z prawem naturalnym i „głosem słuszności”.

Ostatnim przykładem poglądów E. Jarry, w których można dostrzec związki z filozofią Kanta, jest podejście do państwa, w którym realizuje się idea jedności obywatelskiej. Eksponowana jednak przez E. Jarrę rola państwa jako jedynie racjonalnego porządku prawnego, w którym dominującą rolę odgrywają obowiązki oraz interes społeczny nad interesem jednostki - bez uwzględnienia zupełnie idei wolności - stawia go wśród przedwojennych orędowników rządów autorytarnych bądź totalitarnych. Brak powiązania idei jedności obywatelskiej z kantowską koncepcją republikanizmu oraz państwa celów przez E. Jarrę może skłonić do popełnienia interpretacyjnego błędu, iż stanowisko Kanta bliższe jest rozwiązaniom ustrojowym III Rzeszy niż państwa demokratycznego (liberalnego ${ }^{103}$. Natomiast powojenne teorie państwa prawnego wymieniają właśnie kantowską koncepcję jako jeden $\mathrm{z}$ modelowych archetypów współczesnego państwa demokratycznego ${ }^{104}$.

103 „Kant w literaturze czasów ostatnich zostaje z naciskiem odsądzony od liberalizmu i indywidualizmu zarówno przez zwolenników, jak i przeciwników tych kierunków. Gdy przy tym jedni zarzucają mu deifikację państwa, głoszenie jego wszechmocy, etatyzm i centralizm, inni poczytują za zasługę, że ocenił wartość człowieka nie ze stanowiska jednostki, jej przyrodzonych praw podmiotowych, lecz z wysokiego piedestału zadań całości narodu; podnosząc nawet, że ograniczając swobodę jednostki celami ogółu, pogłębił jej sens, podniósł jej godność, na podobieństwo nauki Chrystianizmu. Uniwersalistyczne stanowisko Kanta uwydatnia się szczególnie w jego nauce o jedności obywatelskiej”: E. Jarra, Jedność obywatelska..., s. 49.

104 Zob. S. Gałkowski, Kant i totalitaryzm? s. 87-98; R. Kozłowski, Kant o demokracji (zarys problematyki), [w:] Filozofia a demokracja, s. 105-108. 